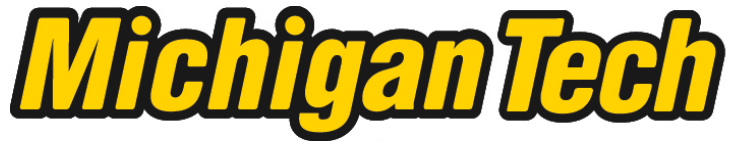 \\ Michigan Technological University Create the Future Digital Commons @ Michigan Tech
}

Dissertations, Master's Theses and Master's Reports - Open

Dissertations, Master's Theses and Master's

Reports

2012

\section{Selecting an electrical power source at the scoping level for a mining project}

Christopher Dawson Van Arsdale

Michigan Technological University

Follow this and additional works at: https://digitalcommons.mtu.edu/etds

Part of the Mining Engineering Commons

Copyright 2012 Christopher Dawson Van Arsdale

\section{Recommended Citation}

Van Arsdale, Christopher Dawson, "Selecting an electrical power source at the scoping level for a mining project", Master's report, Michigan Technological University, 2012.

https://doi.org/10.37099/mtu.dc.etds/542

Follow this and additional works at: https://digitalcommons.mtu.edu/etds

Part of the Mining Engineering Commons 


\title{
SELECTING AN ELECTRICAL POWER SOURCE AT THE SCOPING LEVEL FOR A MINING PROJECT
}

By:

Christopher Dawson Van Arsdale

\begin{abstract}
A REPORT
Submitted in partial fulfillment of the requirements for the degree of MASTER OF SCIENCE

Mining Engineering
\end{abstract}

MICHIGAN TECHNOLOGICAL UNIVERSITY

2012 
This report, "Selecting An Electrical Power Source At The Scoping Level For A Mining Project," is hereby approved in partial fulfillment of the requirements for the Degree of MASTER OF SCIENCE IN MINING ENGINEERING.

Department of Geological and Mining Engineering and Sciences

Signatures:

\begin{tabular}{cl} 
Report Advisor & \\
\cline { 2 - 2 } Report Co-Advisor & \\
& \\
Depart Stanley J. Vitton \\
Date & \\
\hline
\end{tabular}




\section{Abstract:}

The electrical power source is a critical component of the scoping level study as the source affects both the project economics and timeline. This paper proposes a systematic approach to selecting an electrical power source for a new mine. Orvana Minerals Copperwood project is used as a case study. The Copperwood results show that the proposed scoping level approach is consistent with the subsequent much more detailed feasibility study. 


\section{Introduction}

A key component in the development of any new mining project is in the infrastructure assessment and cost needed to develop and operate a mine. For many new mining projects the cost of upgrading and/or developing the required infrastructure can be significant and can affect the mine's potential for development. Major infrastructure components commonly include electrical power, water, and transportation of product from the mine. For rural and highly underdeveloped areas, these infrastructure costs can be significant.

A critical infrastructure component for almost all mining projects is the availability of electrical power and becomes an important component at the scoping level of the development for a new mining project. The options for an electrical power source can often be quickly limited to only a couple of options, and in many cases one option. The purpose of this paper is to discuss the approach used for selecting an electrical power source based on a case study of the Copperwood project located in a rural section of northern Michigan. In the Copperwood case study, there were several obvious options, but based on limited information available at the scoping level, there was no readily apparent best solution without systematic analysis.

Orvana Minerals Corporation graciously allowed publication of this paper. The results and interpretations herein are the responsibility of the author.

\section{Background}

One of the early steps in evaluating a potential new mining operation is a scoping level study that analyzes the technological and economic challenges of the site. The scoping level is the first of three studies that is then followed by a prefeasibility and feasibility study, each with a higher level of confidence (Mackenzie 2007).

The scoping level identifies all of the probable components of a new potential mining project (Adams 2006). Its goal is to "define the potential of a project, eliminate those options that are unlikely to become optimal, and determine if there is sufficient opportunity to justify the investment required for further studies"(Adams 2006). Since only preliminary design work for a potential mine and concentrator plant is completed at the scoping level, estimates for costs are rough approximations with accuracy of plus or minus 30\% to 50\% (Rupprecht 2004). Estimates for equipment and required infrastructures can be determined based on: other analogous projects with similar ore grade, mining method, and general geographic challenges; on industry standards; or on preliminary design information if available (Adams 2006). The options to meet these infrastructure needs must be sorted into viable and not viable; then into optimal and sub-optimal based on company priorities. Finally, decisions of cost effectiveness will decide which electrical power source is selected. 
Many studies at the scoping level only identify a single available electrical power source with little to no mention of alternatives, giving the impression that alternatives were not thoroughly evaluated. The decision for an electrical power source has typically come down to which of the viable options is cheapest, often ignoring many of the other important factors and trade-offs that may show that the cheapest option is not necessarily optimal. Furthermore, the costs are typically based only on the mine's total power demand and the distance from the electrical power source, rather than looking at how other characteristics of an electrical power source may affect the mine.

The approach discussed in this paper is based on the determination of the best available electrical power source available for the proposed Orvana Minerals Corporation's Copperwood project, in Gogebic County, Michigan.

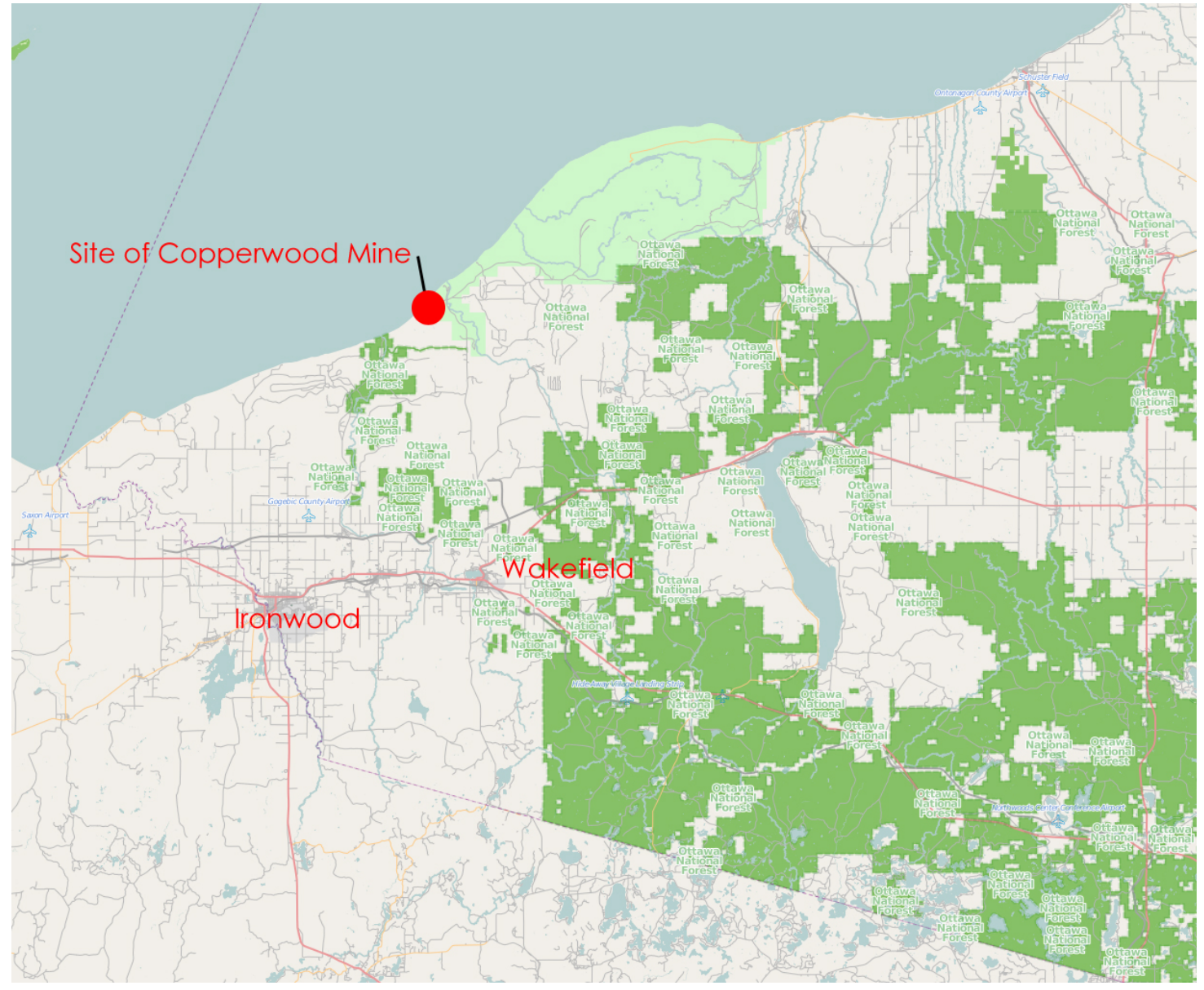

Figure 1: Copperwood site. $\odot$ OpenStreetMap contributors, CC BY-SA

The proposed Copperwood project represents a potentially new mine to extract a tabular dipping copper ore body via underground mining operations (Keane 2012). At the scoping level, the proposed mining method assumed that mechanical mining methods using a continuous miner would be feasible to mine the ore using a room 
and pillar mining method. Removal of the ore from the mine was to be accomplished using haul trucks that would haul the rock to the surface via a box cut made through 30 meters of soils to bedrock.

The scoping level envisioned that, once on the surface, the ore would be processed on site in a new concentrator plant designed to handle 5,000 tpd. The scoping level design of the concentrator plant utilized a rod mill followed by a ball mill to grind the ore to the appropriate particle size. The ore would then be floated to separate out the copper with regrinding taking place at several stages of the separation. Overall, the concentrating plant would constitute the majority of the electrical load of the mine site due to the grinding required for ore partial size reduction.

At the scoping level, the proposed operation was similar, except for size, to that actually used at the dormant White Pine Mine, located 34km east of the proposed Copperwood mine and closed in 1995. While the While Pine Mine operated for over 50 years, the total copper endowment of the Copperwood project is much smaller than the White Pine Mine, at about one-fifth the size and a proposed operating life of about eight years.

After the scoping level study was completed, both the prefeasibility and feasibility studies were completed for Copperwood. The completed feasibility study gives the opportunity to validate the approach taken in this paper by comparing the error between the two levels of accuracy (scoping level versus feasibility). Mining method and concentrating plant changes between the scoping level and feasibility level studies affected the power demand, and therefore, potentially the viability of the electrical power source.

\section{Options for Providing Electrical Power}

Selecting an electrical power source begins by identifying the viable sources. Primary sources, or sources that can reliably provide fulltime power to a facility, generally fall into two categories: electric utility connections and on-site generation.

For electric utilities, obtaining information on reliability, load capacity, general rate information, and potential points of interconnection are necessary for an accurate evaluation. On-site generation options usually involve diesel or gas powered generators and multiple machines operating in parallel to meet the needs of the facility. Supplemental energy sources should also be considered. While these sources would not provide full-time electrical power to the mine, they could be used in conjunction with a primary electrical power source to reduce the operational costs of the mine and perhaps to demonstrate good stewardship. Some electrical power sources are not viable at this time such as small-scale, self-contained nuclear power sources because of the potential political and permitting issues associated with them. 
Copperwood's location had more than one electric utility from which power might be obtained; this was somewhat unusual (Table 1). The site was within range of both Xcel Energy, (approximately $46 \mathrm{~km}$ to the nearest suitable substation) and White Pine Electric Power (approximately $34 \mathrm{~km}$ to the point of connection). The on-site options at Copperwood were diesel generation, whereas diesel fuel would be transported via truck to the site, or natural gas based generation, in which case a 24 $\mathrm{km}$ long natural gas pipeline would need to be constructed.

Table 1: Copperwood source identification

\begin{tabular}{|l|l|l|}
\hline \multicolumn{2}{|c|}{ Primary Sources } & Supplemental Sources \\
\hline Off-site (Utility) & On-site (Generators) & \\
\hline Xcel Energy & Diesel & Solar \\
\hline $\begin{array}{l}\text { White Pine Electric } \\
\text { Power }\end{array}$ & Natural Gas & Wind \\
\hline
\end{tabular}

\section{Analyzing Scoping Level Electrical Power Sources}

\section{Step 1: Identify the Loads}

The first step in selecting an electrical power source is to determine the required electrical load. This can be accomplished using two approaches: using estimates based on analogy and on preliminary design information. Analogy uses similar past projects or standard data tables, such as the Western Mine Engineering Handbook (Gosling 1999), to estimate the electrical load. Using an analogy requires similar mine and concentrating facility data to be available. Standard tables are based on the average production of a facility using a standard concentrating process for a particular type of ore. The electrical load at the scoping level can also be estimated using information from the preliminary mine and concentrator design. Using two independent estimates helps insure valid conclusions are drawn.

For Copperwood, the scoping study electrical load was determined using analogy from two sources: the former White Pine Mine, and the Western Mine Engineering handbook tables. The White Pine Mine power plant capacity was 53MW and the production rate of the mine was approximately 17,000 tpd (EPA 1992). When scaled to Copperwood's expected maximum production, a conservative estimate of 15.6MW or 17.3MVA using a 0.9 lagging power factor resulted. Using the Western Mine Engineering Handbook the load was estimated based on the expected daily throughput of $5000 \mathrm{tpd}($ Keane 2012) with additions for the expected underground equipment and ancillary surface facilities. The handbook estimate was $13 \mathrm{MW}$ or 15MVA (Table 2). 
Table 2: Estimates of scoping level electrical load for Copperwood

\begin{tabular}{|l|l|l|}
\hline Method: & Concentrator Load: & Total Facility Load: \\
\hline $\begin{array}{l}\text { Analog: White Pine Mine } \\
\text { and concentrator plant }\end{array}$ & $\begin{array}{l}\text { Not separated out from } \\
\text { mining or ancillary loads }\end{array}$ & $17.3 \mathrm{MVA}$ \\
\hline $\begin{array}{l}\text { Analog: Western Mine } \\
\text { Engineering Handbook }\end{array}$ & $6 \mathrm{MVA}$ & $15 \mathrm{MVA}$ \\
\hline $\begin{array}{l}\text { Preliminary Design: Mine } \\
\text { and concentrator design }\end{array}$ & $11.5 \mathrm{MVA}$ & $17.3 \mathrm{MVA}$ \\
\hline
\end{tabular}

These values are assuming: power factor of 0.9 lagging, 5000tons/day production with similar ore and host rock to the White Pine Mine.

The preliminary design information also identifies the largest motor sizes at the facility. This information is needed to account for the required inrush current from the electrical power source. It is important to recognize that at a scoping level, failure to account for the largest motor may invalidate a source at a later point in time if the electrical power source cannot provide this inrush current. This can affect the final design of the concentrator plant or the mining method options by limiting the largest motor that can be used.

Based on the scoping level concentrating plant design, it was expected that the largest motor for Copperwood would be the ball mill at 5,000HP. It was also expected that this mill would have a duty cycle of $100 \%$. The rod mill would be the second largest motor at 2,000HP and the regrind mill the third largest at 750HP. There was also an assumption that these three mills will not start simultaneously so the electrical power source needed only to handle the inrush was from the largest motor.

The two methods of load estimating for Copperwood showed very similar estimates for the total electrical load. The both analogies showed 15-17.3MVA, and the preliminary design information also showed 17.3MVA. Typically, the larger of the two would be taken as the maximum expected load or 17.3 MVA.

\section{Step 2: Consider the Trade-offs}

In this step, the analysis of electrical power sources involves the trade-offs between competing objectives that are addressed through a series of yes or no questions. Negative answers can sometimes be "traded-off" by increasing some "other" characteristic of the source. For example, reliability can be improved by having additional on-site generators, or redundant feeds from a utility, but both would incur additional costs. Table 3 provides a list questions dealing with the required information for each electrical power source along potential mitigation methods in the event of negative answers. Figure 2 illustrates how the decisions can be a made to either reject or mitigate an electrical power source. 


\section{Table 3: Analysis of scoping level trade-offs}

\begin{tabular}{|c|c|c|}
\hline Question & Information Needed & Mitigation Methods \\
\hline $\begin{array}{l}\text { Is the time frame } \\
\text { acceptable? }\end{array}$ & $\begin{array}{l}\text { Expected installation and } \\
\text { startup times } \\
\text { Expected lead-time for } \\
\text { equipment, e.g., power } \\
\text { line permitting and } \\
\text { construction, } \\
\text { transformers, protection } \\
\text { equipment } \\
\end{array}$ & $\begin{array}{l}\text { Could temporary power } \\
\text { be available until the } \\
\text { permanent primary } \\
\text { electrical power source is } \\
\text { available? If so, what } \\
\text { would be the additional } \\
\text { cost? }\end{array}$ \\
\hline $\begin{array}{l}\text { Does electrical power } \\
\text { source meet the desired } \\
\text { level of reliability? }\end{array}$ & $\begin{array}{ll}\text { Electrical power source } \\
\text { reliability statistics } \\
\text { - Single mode failure } \\
\text { analysis } \\
\text { Acceptability of } \\
\text { downtime at the mine or } \\
\text { concentrator plant }\end{array}$ & $\begin{array}{l}\text { Can additional stand-by } \\
\text { electrical power sources } \\
\text { be used to improve } \\
\text { reliability to desired } \\
\text { level? If so, what would } \\
\text { be the cost? } \\
\text { - Can additional } \\
\text { redundancy be built into } \\
\text { the system? If so, what } \\
\text { would be the cost? }\end{array}$ \\
\hline $\begin{array}{l}\text { Would there be } \\
\text { environmental issues that } \\
\text { can effect permitting? }\end{array}$ & 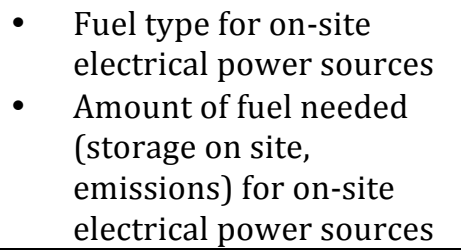 & $\begin{array}{l}\text { Is an alternative fuel } \\
\text { available? If so, what } \\
\text { additional cost? } \\
\text { Can the amount of stored } \\
\text { fuel be reduced without } \\
\text { reducing reliability? }\end{array}$ \\
\hline
\end{tabular}



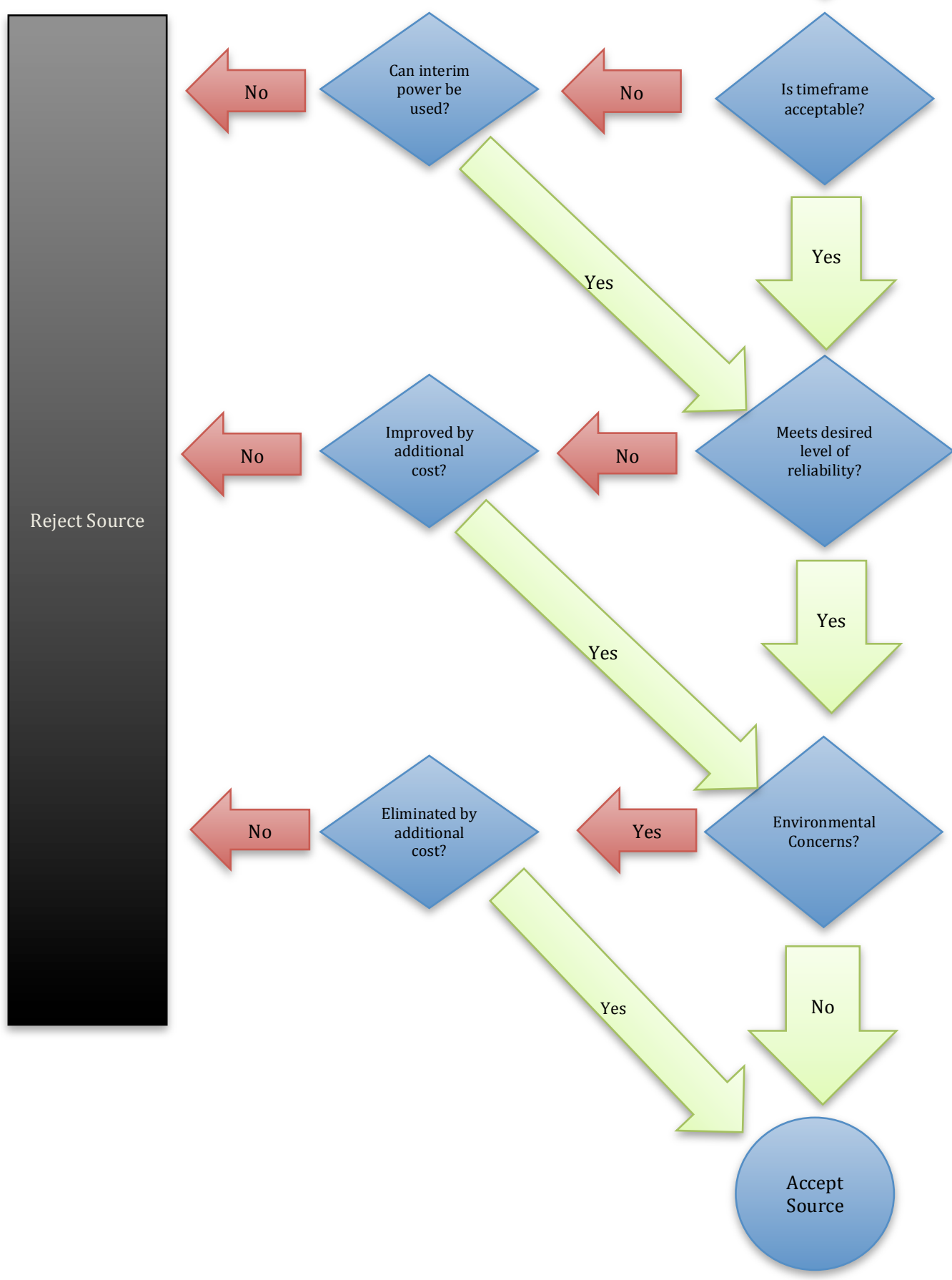

Figure 2: Second Step Evaluation 
The results of the second step in the analysis of the Copperwood scoping level for the selection of an electrical power sources is provided in Table 4. This table lists the analysis of the electrical power sources at the scoping level, based on the company's priorities.

Table 4: Second analysis of electrical power sources for Copperwood

\begin{tabular}{|c|c|c|c|c|}
\hline Question & Xcel Energy & White Pine EP & $\begin{array}{l}\text { Diesel } \\
\text { Generators }\end{array}$ & $\begin{array}{l}\text { Natural Gas } \\
\text { Generators }\end{array}$ \\
\hline $\begin{array}{l}\text { Is the time frame } \\
\text { acceptable? }\end{array}$ & $\begin{array}{l}\text { Yes, } 18 \text { months. } \\
\text { Sooner if } \\
\text { temporary } \\
\text { generators used }\end{array}$ & $\begin{array}{l}\text { No: } \\
6 \text { months for } \\
\text { construction } \\
\text { but right-of - } \\
\text { way would } \\
\text { need to be } \\
\text { secured by } \\
\text { Orvana }\end{array}$ & $\begin{array}{l}\text { Yes, } 12 \\
\text { months }\end{array}$ & $\begin{array}{l}\text { No, } 12-18 \\
\text { months for } \\
\text { construction but } \\
\text { gas transmission } \\
\text { company under } \\
\text { force majeure } \\
\text { for unknown } \\
\text { period of time. }\end{array}$ \\
\hline $\begin{array}{l}\text { Does electrical } \\
\text { power source } \\
\text { meet the desired } \\
\text { level of } \\
\text { reliability? }\end{array}$ & Yes & $\begin{array}{l}\text { No, single } \\
\text { source facility }\end{array}$ & Yes & $\begin{array}{l}\text { No, recent } \\
\text { pipeline rupture } \\
\text { near the likely } \\
\text { point of } \\
\text { connection. }\end{array}$ \\
\hline $\begin{array}{l}\text { Would there be } \\
\text { environmental } \\
\text { issues obtaining } \\
\text { a permit? }\end{array}$ & No & No & $\begin{array}{l}\text { Emissions } \\
\text { permits, on- } \\
\text { site storage } \\
\text { of fuel } \\
\text { permits. }\end{array}$ & $\begin{array}{l}\text { Emissions } \\
\text { permits. }\end{array}$ \\
\hline Accepted? & Yes & No & Yes & No \\
\hline
\end{tabular}

* This natural gas pipeline ruptured in June of 2009 near Bessemer(Neese 2009)

\section{Step 3: Economic Analysis}

The final step in this approach examines the capital and operating costs of the remaining electrical power sources. In this analysis, it was assumed that capital costs were paid for upfront (prior to the start of construction). However, this may not always be the case as some utilities will allow capital costs to be spread out over the course of the expected life of the project through higher electrical use rates.

There are additional capital costs for on-site distribution of electricity regardless of the electrical power source. These include the cost of the mine owned substation that houses the transformers, protection and voltage regulation devices, and serves as the tie point to the electrical power source. The medium voltage distribution system at the mine will also be the same regardless of the source. This will include the lines from the substation to the individual buildings where it will be reduced to a usable voltage for machinery utilization. For this analysis, the mine electrical distribution system was not included in the cost comparisons because this will be common, regardless of the electrical power source selected. However, 
infrastructure specific to the electrical power source is included, e.g. diesel storage tanks, if diesel generators are selected.

It is also possible to phased capital costs with some electrical power sources. Onsite generators for example could be purchased in phases where an initial set of generators provides electrical power for the first years, during construction, with additional generators added as production starts and ramps up towards full capacity. This phasing can be accounted for in the overall mining project economic analysis done at the scoping level.

The operating costs are based on power consumption and the electrical rate of the utility or on-site generation sources (fuel costs). For the latter, maintenance costs are also included in the operational cost. Table 5 lists the relevant questions for making the final decision. For this step, all electrical power sources are compared to each other rather than to a static metric. The company must decide which has priority: capital or operating costs. Based on this decision, the lowest cost for the desired category becomes the choice for the electrical power source.

Table 5: Economic analysis

\begin{tabular}{|l|rl|}
\hline Comparison & Information Needed from each source \\
\hline $\begin{array}{l}\text { Capital cost: installation, infrastructure } \\
\text { required on-site if self-generation. }\end{array}$ & $\begin{array}{l}\text { Capital costs of equipment. Fuel } \\
\text { storage requirements. } \\
\text { Desired "on-hand" fuel storage } \\
\text { (based on the number of days of } \\
\text { operation without resupplying). } \\
\text { Additional costs from offsets } \\
\text { (from step 2). }\end{array}$ \\
\hline $\begin{array}{l}\text { Operational costs: } \\
\text { Fuel costs, maintenance costs }\end{array}$ & $\begin{array}{l}\text { Electricity consumption } \\
\text { - }\end{array}$ \\
& $\begin{array}{l}\text { Fuel consumption per year } \\
\text { methource and transportation }\end{array}$ \\
& $\begin{array}{l}\text { Maintenance costs per year } \\
\text { Additional costs from offsets } \\
\text { (from step 2). }\end{array}$ \\
\hline
\end{tabular}

For Copperwood at the scoping level, the costs were examined for the two acceptable electrical power sources (Table 6). It is important to remember that at the scoping level the estimated costs are $+/-30 \%-50 \%$. 
Table 6: Final analysis of sources

\begin{tabular}{|l|l|l|}
\hline Comparison & Xcel Energy & $\begin{array}{l}\text { Diesel } \\
\text { Generators }\end{array}$ \\
\hline $\begin{array}{l}\text { Capital cost: } \\
\text { installation, } \\
\text { infrastructure } \\
\text { required on site if self- } \\
\text { generation. }\end{array}$ & $\$ 16.5 \mathrm{M}$ & $\$ 12 \mathrm{M}-18 \mathrm{M}$ \\
\hline $\begin{array}{l}\text { Operational costs per } \\
\text { year: }\end{array}$ & $\$ 5.2 \mathrm{M}$ & \\
$\begin{array}{l}\text { Fuel costs, } \\
\text { maintenance costs }\end{array}$ & $\$ 16 \mathrm{M}-\$ 27 \mathrm{M}^{*}$ \\
\hline $\begin{array}{l}\text { Selection: } \\
\text { Better electrical } \\
\text { power source }\end{array}$ & \\
\hline
\end{tabular}

*Based on $\$ 3.00 /$ gallon diesel fuel (including delivery)

The economic analysis for Copperwood clearly indicates that Xcel Energy should be the electrical power source. Xcel met the capacity requirements and was relatively straightforward in regards to the permitting process. The cost comparison between the Xcel and the generator option reveals that while the capital costs for both Xcel and the diesel generation sources were similar, the operating costs were considerably different. The lower operating cost made Xcel the better option for the Copperwood Project. However, Xcel did have a longer lead-time and lower reliability than the on-site generator options. There were generally minor on-site environmental concerns with the utility.

Supplemental electrical power could provide benefit in terms of operational cost savings or could politically help in building community support for the project. For example, looking at the potential for wind generation at the site, the power generated could be used to reduce the amount of power purchased from Xcel. However, there would be additional capital costs (as much as \$7.8M for two turbines) and there would also be maintenance costs, which could range from $\$ 0.03-\$ 0.06 / \mathrm{kWh}$ generated. This means that it was possible that Copperwood could save $\$ 0.01 / \mathrm{kWh}$ but it could also cost an additional $\$ 0.02 / \mathrm{kWh}$. If the electric rate from Xcel were higher or if there were government (state or federal) subsidies or tax breaks then the economics of these supplemental sources might be more favorable.

\section{Comparison Between Feasibility and Scoping Level Results}

The feasibility study for Copperwood can be used to validate the scoping level approach to selecting the electrical power source described above. The feasibility study designates Xcel Energy as the expected electrical power source. The feasibility study is more detailed with smaller error as more design work has been 
completed. The scoping level and feasibility study electrical power source costs are well within the errors established for these studies (Table 7).

Since the completion of the scoping level study, there have been some relevant changes to the mine and concentrator plan, which makes a direct comparison difficult. The mining method was changed to a drill and blast method rather than mechanical mining, which reduced electrical power demand. At the same time, conveyors replaced haul trucks for moving the ore from the mine to the concentrator plant, which increased electrical power demand. In the concentrator plant, the rod mill was replaced with a semi-autogenous grinding mill (SAG). The concentrator plant was also to be installed in phases with the first phase at the 5,000 tpd (planned full capacity at the scoping level), but the feasibility study added a second phase (to be completed in year three of production) to increase production to 7,500tpd (Keane 2012). Thus, the full production capacity of the concentrating plant was $50 \%$ greater in the feasibility study than at the scoping level. This increase is reflected in the higher feasibility electrical load (Table 7).

Table 7: Scoping and Feasibility Comparison for Copperwood

\begin{tabular}{|c|c|c|c|}
\hline & Scoping Level & Feasibility* & Change \\
\hline Electrical Load & 17.3MVA & $24 \mathrm{MVA}^{* *}$ & $+6.7 \mathrm{MVA}^{* *}$ \\
\hline Capital Costs & $\$ 16.5 \mathrm{M}$ & $\$ 16.8 \mathrm{M}$ & $+\$ 0.3 \mathrm{M}$ \\
\hline $\begin{array}{l}\text { Operating Costs (per } \\
\text { year) }\end{array}$ & $\$ 5.2 \mathrm{M}$ & $\$ 5.4 \mathrm{M} / \$ 9.6 \mathrm{M}^{* * *}$ & $+\$ 0.2 \mathrm{M} /+\$ 4.4 \mathrm{M}^{* * *}$ \\
\hline
\end{tabular}

These results show that the approach used in the scoping level provided a reasonable approximation for electrical power source information. The same electrical power source was selected out of the four options at both the scoping level and feasibility study. The estimated scoping level electrical load is within $13.5 \%$ of the feasibility number (without the extra capacity included in the feasibility number). The capital and operating costs were also similar when using the same daily production rate.

\section{Conclusion and Recommendations:}

The electrical power source accounts for a significant portion of the capital and operating costs of a new mine project and thus, it is important that at the scoping level, the potential costs associated with the various possible electrical power sources are understood. In addition to cost, it is important to consider other aspects of the electrical power source such as time frame requirements of the given source, environmental and permitting issues, and the reliability. Some of these characteristics can be exchanged or modified at the expense of other characteristics or costs. 
The order of the approach described here illustrates the importance of accurate load information. Significant changes in load, or even individual large motors can invalidate electrical power sources regardless of cost priorities. The proposed approach is sufficiently robust enough to use for any mine and location. It can also be adjusted to the situational environment by adjusting which issues are most important to the company. At the scoping level the systematic approach is the best guide for determining an electrical power source for a mining project.

\section{Acknowledgements}

The author would like to acknowledge the assistance and co-operation of Orvana Minerals Corporation in for the opportunity to work with this project. Dave Anderson and Bill Williams provided the opportunity for the author to participate in this process from the ground up. Orvana Minerals Corporation provided financial support for the Copperwood work. 


\section{References}

Adams, D. J. N. C. (2006). Effective Mining Project Management Systems. International Mine Management Conference. Melbourne, Vic.: 87-96.

EPA (1992). Mine Site Visit: Copper Range Company White Pine Mine. U. S. E. P. Agency. Washington, D.C., U.S. Environmental Protection Agency.

Gosling, B. B. W. M. E. (1999). Mine and Mill Equipment Costs :An Estimator's Guide. Spokane, Wash., Western Mine Engineering: 70-71.

Keane, J. M. M., Steve; Kerr, Thomas (2012). Feasibility Study of the Copperwood Project, Upper Peninsula, Michigan, USA NI 43-101 Technical Report: KD Engineering, SEDAR published report.

Mackenzie, W. C., N. (2007). The Use and Abuse of Feasibility Studies. Project Evaluation Conference. Melbourne, Vic.

Neese, G. (2009). Work Ongoing on Natural Gas Pipeline. The Daily Mining Gazette. Houghton.

Rupprecht, S. (2004). Establishing the Feasibility of Your Proposed Mining Venture. International Platinum Conference "Platinum Adding Value", The South African Institute of Mining and Metallurgy: 243-248. 